\title{
ASPECTS OF THE MAGNETITE CRYSTALLINE STRUCTURE A BRIEF OVERVIEW OF NANOMAGNETISM
}

SAMPAIO, Guilherme Moisés ${ }^{1}$

BRANDL, Ana Lúcia ${ }^{2}$

SUMMARY: This article aims to present briefly the relation of the origin of the magnetic behavior at nanoscale with the influence of the crystalline structure of the respective particulate material in question - [magnetite $\left.\left(\mathrm{Fe}_{3} \mathrm{O}_{4}\right)\right]$. In general, we intend to give an insight into the understanding of the properties and fundamentals of the macroscopic interactions of magnetic solids in a microscopic picture.

Keywords: Magnetite. Crystalline structure. Magnetic behavior. Nanomagnetism.

\section{ASPECTOS DA ESTRUTURA CRISTALINA DA MAGNETITA UMA BREVE VISÃO GERAL DO NANOMAGNETISMO}

RESUMO: Este artigo tem por objetivo apresentar brevemente a relação da origem do comportamento magnético em nanoescala com a influência da estrutura cristalina do respectivo material particulado em questão - [magnetita $\left(\mathrm{Fe}_{3} \mathrm{O}_{4}\right)$ ]. De modo geral, pretende-se dar uma visão sobre a compreensão das propriedades e fundamentos das interações macroscópicas de sólidos magnéticos em um quadro microscópico.

Palavras-chave: Magnetita. Estrutura cristalina. Comportamento magnético. Nanomagnetismo.

\section{INTRODUCTION}

The emergence of new properties that are currently the object of study of Nanomagnetism lies in the fact that the magnetic behavior of nanometric materials differs considerably from the classical magnetism found in macroscopic materials (bulk type).

In this context, magnetic nanoparticles (magnetic NPs) play an important role in several fields of Science and Technology, which include areas such as Materials Science, Physics, Medicine, Biology, among others.

The synthesis of these magnetic NPs, associated with the great technological potential that they present, has been a topic of great interest on the part of the scientific community in the last decades, not only for reasons of practical purposes, but also, from a point of view of its Basic Science. Its unique magnetic, optical and chemical properties stand out in this sense (GUBIN, 2009; FIGUEIREDO and SCHWARZACHER, 2007; COWBURN, KOLTSOV, ADEYEYE, WELLAND and TRICKER, 1999).

\footnotetext{
${ }^{1}$ Universidade Federal de São Carlos / UFSCar - [Campus Sorocaba] / Programa de Pós-Graduação em Ciência dos Materiais.

${ }^{2}$ Universidade Federal de São Carlos / UFSCar - [Campus Sorocaba] / Departamento de Física, Química e Matemática - [DFQM].
} 


\section{CRYSTALLINE STRUCTURES}

It is usual to consider a crystal as a natural object with well defined external geometric characteristics, such as those found in, for example, rock salt (halite), graffiti, diamonds, among others.

Until the end of the nineteenth century, the detailed investigation of the external forms of these natural crystals directed the researchers to the conclusion that these regularities of the outer faces were due to structural patterns present on the microscopic scale. Molecules and atoms had to be arranged periodically in order to form a crystal.

Nowadays, these structures can be investigated experimentally by direct observation or by the diffraction of an electromagnetic radiation (X-ray crystallography). These experimental analytical mechanisms show that many solids actually have a crystalline structure, even when their outer surfaces do not give us this impression.

In this sense, these solids are, in fact, polycrystalline, that is to say, constituted by a series of small crystalline grains, being that the number of atoms present in a perfectly crystalline environment is still very large when compared to the number of atoms on the grain boundary (HOFMANN, 2015).

In this perspective, the study and understanding of the structure of polycrystalline materials is of great importance not only for Solid State Physics but also for a wide range of problems and situations involving Nanotechnology and Structural Biology.

\section{MAGNETIC DOMAINS}

All materials exhibit some magnetic behavior, depending on the response that the atomic magnetic moments have under the application of an external magnetic field (SINNECKER, 2000).

Each atom behaves like a tiny permanent magnet and, spontaneously, aligns itself parallel to its neighbors in regions within the material. These characteristic regions, in which a single magnetic alignment predominates, are called magnetic domains (KITTEL, 1946; LANDAU and LIFSHITS, 2008; GUIMARÃES, 2000).

In this aspect, the atomic magnet behaves differently from the macroscopic permanent magnet, which tends to align antiparallelly, as schematically represented by [Figure 1]. It is important to note that this is the lowest power configuration for each system.

Figure 1 - Parallel alignment of atomic moments and antiparallel of permanent magnets.

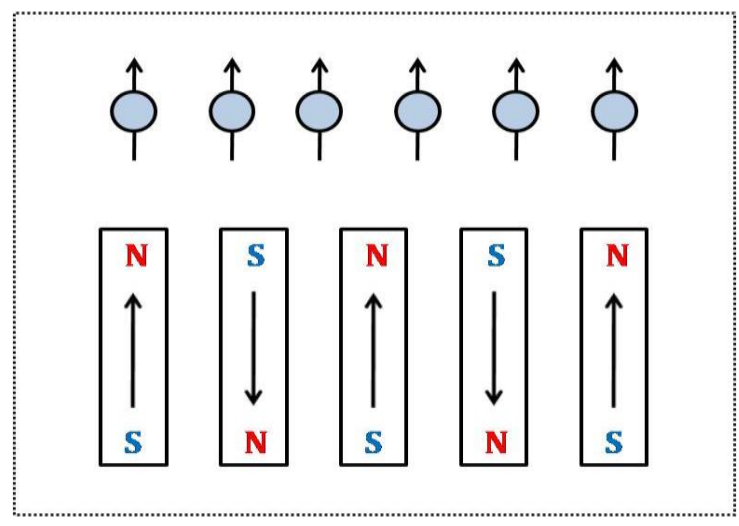

Source: (Adapted from FARIA and LIMA, 2005).

Although these regions are spontaneously magnetized in a fixed direction, the magnetic domains 
in the material are randomly arranged relative to one another in order to minimize the overall energy of the system, as schematically represented by [Figure 2].

Figure 2 - Schematic representation of the structure of the magnetic domains arranged randomly in a polycrystalline material. In this case, each monocrystalline grain contains a single magnetic domain. In this condition, the material is demagnetized, that is, it does not produce an external magnetic field.

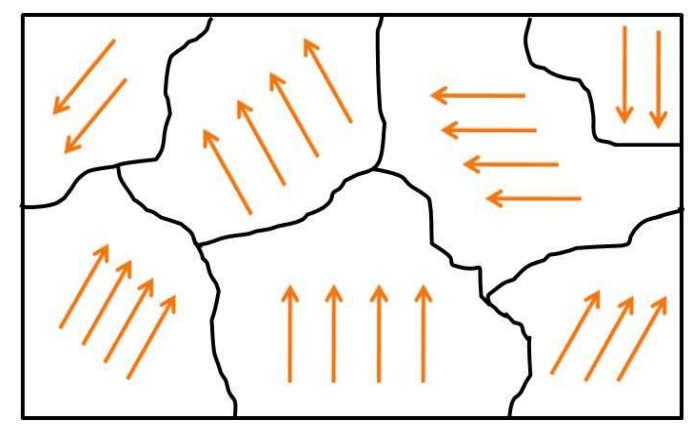

Source: (Adapted from FARIA and LIMA, 2005).

In polycrystalline materials, each monocrystalline grain having dimensions ranging from $(10 \mu \mathrm{m})$ to $(1000 \mu \mathrm{m})$, contains many magnetic domains. An arrangement in which all magnetic domains are aligned in one direction will produce an external magnetic field.

It is important to note that both paramagnetism and ferromagnetism depend on unpaired electrons, but only ferromagnetic materials present the formation of these domains. These include iron, cobalt, nickel and alloys of these elements with some rare earths and are simply referred to as magnetic materials.

Although the denomination non-magnetic materials is widely used for diamagnetic materials and also for paramagnetic materials, strictly speaking, only the vacuum can be considered in fact nonmagnetic, as we pointed out at the beginning of this topic.

\section{CUBIC STRUCTURE OF INVERSE SPINEL - MAGNETITE}

Magnetite $\left(\mathrm{Fe}_{3} \mathrm{O}_{4}\right)$ is a magnetic mineral composed of $\left(\mathrm{Fe}^{2+}\right)$ and $\left(\mathrm{Fe}^{3+}\right)-\left(\mathrm{FeO}\right.$ and $\left.\mathrm{Fe}_{2} \mathrm{O}_{3}\right)$ oxides, with approximately $69 \%$ of $(\mathrm{FeO})$ and $31 \%$ of $\left(\mathrm{Fe}_{2} \mathrm{O}_{3}\right)$ in its composition (SAFARIKOVA and SAFARIK, 2001).

This ore presents a cubic crystalline structure of the inverse spinel type, as schematically represented by [Figure $3(\mathrm{~A})$ and $(\mathrm{B})]$.

Figure 3 - (A) Representation of the structure of a natural magnetite crystal and (B) illustrative representation of cubic crystalline structure of the inverse spinel type.
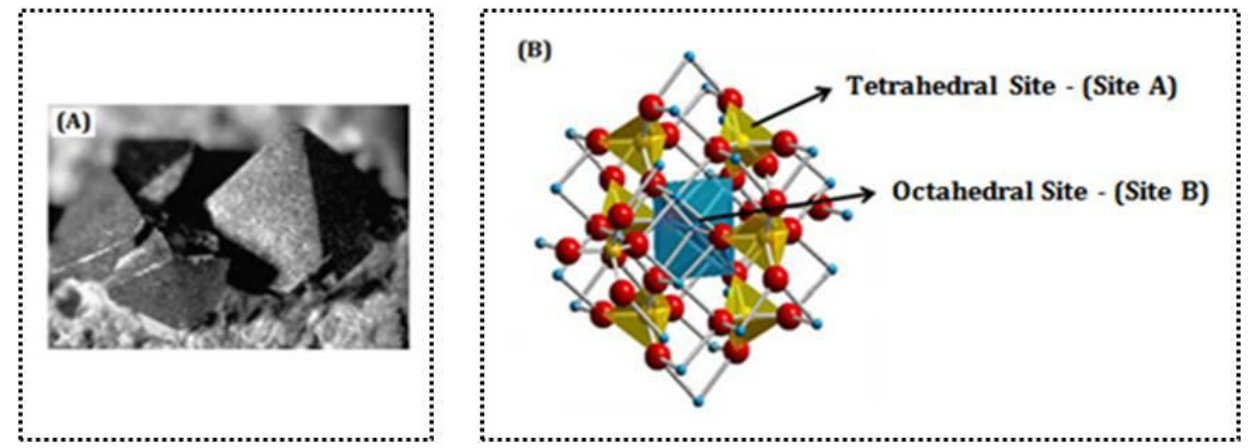

Source: (Adapted from SCHULZ, SHANOV and YUN, 2009). 
In this type of crystalline structure, each unit cell has a general formula described by $\left(\mathrm{A}_{8} \mathrm{~B}_{12} \mathrm{O}_{32}\right)$ in which the oxygen atoms are usually distributed in cubic positions, whereas the $\left(\mathrm{Fe}^{2+}\right)$ and $\left(\mathrm{Fe}^{3+}\right)$ cations occupy the spaces between the oxygen ions.

These spaces occupied by iron cations can be of two forms, the so-called Tetrahedral Sites - (Site A), in which the cation occupies the center of the tetrahedral structure, and has as corners of this geometry the oxygen atoms; and the so-called Octahedral Sites - (Site B), where the oxygen atoms occupy the vertices of an octahedral geometry and the cation ends up occupying its respective center.

It is known that the magnetite ore presents a natural magnetization, precisely due to this structure of inverse spinel, in which there is the existence of exchange interactions between the cations of the tetrahedral and octahedral sites.

In this sense, the magnetic moments of all $\left(\mathrm{Fe}^{3+}\right)$ cations fixed in the positions of the octahedral sites are aligned in parallel way with each other. However, these cations are positioned in an opposite direction in relation to the other $\left(\mathrm{Fe}^{3+}\right)$ cations present in the positions of the tetrahedral sites, which also are aligned with each other.

This results in an antiparallel coupling of these neighboring iron cations, which causes a reciprocal cancellation of the magnetic moments of all these respective ions, giving no resulting contribution to the total magnetization of the material.

On the other hand, all the $\left(\mathrm{Fe}^{2+}\right)$ cations located in the positions of the octahedral sites present their respective magnetic moments also aligned in the same direction; being this resulting magnetic moment, the one responsible for the total magnetization of our magnetite crystal, [Figure 4].

Figure 4 - Schematic representation of the magnetite $\left(\mathrm{Fe}_{3} \mathrm{O}_{4}\right)$ magnetic moments distribution.

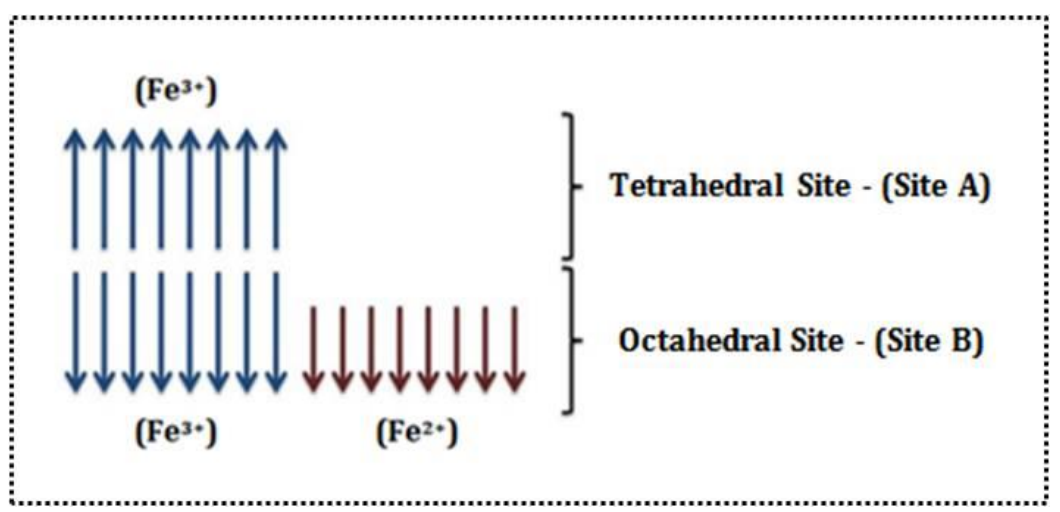

Source: (Adapted from ELLIOTT, 1998).

\section{FINAL CONSIDERATIONS AND CONCLUSION}

Based on this briefly described review, it is concluded that the saturation magnetization of a ferrimagnetic material (such as magnetite) can be calculated by means of the product of the resulting magnetic moment for each $\left(\mathrm{Fe}^{2+}\right)$ cation and the number of these respective cations in the material; which in fact corresponds to the mutual alignment of all magnetic moments of these ions in a sample of $\left(\mathrm{Fe}_{3} \mathrm{O}_{4}\right)$ (CALLISTER and RETHWISCH, 2009).

In this sense, as already noted, this ends up supporting the concept that many types of behavior are actually macroscopic manifestations of microscopic phenomena. 


\section{REFERENCES}

CALLISTER, W. D. JR.; RETHWISCH, D. G. Materials Science and Engineering: An Introduction. New York: 8th ed. John Wiley \& Sons. 2009.

COWBURN, R. P.et al. Single-Domain Circular Nanomagnets. Physical Review Letters, v. 83, n. 5, p. 1042-1045, 1999.

ELLIOTT, S. R. The Physics and Chemistry of Solids. New York: 1st ed. John Wiley \& Sons. 1998.

FARIA, R. N.; LIMA, L. F. C. P. Introdução ao Magnetismo dos Materiais. São Paulo: Editora Livraria da Física. 2005.

FIGUEIREDO, W.; SCHWARZACHER, W. Magnetic relaxation and thermal properties of a twodimensional array of dipolar-coupled nanoparticles. Journal of Physics: Condensed Matter, v. 19, n. 27, p. 1-19, 2007.

GUBIN, S. P. Magnetic Nanoparticles. Weinheim, Germany: 1st ed. Wiley-VCH Verlag GmbH \& Co. KGaA. 2009.

GUIMARÃES, A. P. Propriedades Magnéticas de Sistemas Granulares. Revista Brasileira de Ensino de Física, São Paulo, v. 22, n. 3, p. 382-386, 2000.

HOFMANN, P. Solid State Physics: An Introduction. Weinheim, Germany: 2nd ed. Wiley-VCH Verlag GmbH \& Co. KGaA. 2015.

KITTEL, C. Theory of the Structure of Ferromagnetic Domains in Films and Small Particles. Physical Review, v. 70, n. 11-12, p. 965-971, 1946.

LANDAU, L.; LIFSHITS, E. On the Theory of the Dispersion of Magnetic Permeability in Ferromagnetic Bodies. Ukrainian Journal of Physics, Kharkov, v. 53, p. 14-22, 2008.

SAFARIKOVA, M.; SAFARIK, I. The Application of Magnetic Techniques in Biosciences. Magnetic and Electrical Separation, v. 10, n. 4, p. 223-252, 2001.

SCHULZ, M. J.; SHANOV, V. N.; YUN, Y. Nanomedicine Design of Particles, Sensors, Motors, Implants, Robots, and Devices. Boston: 1st ed. Artech House Publisher. 2009.

SINNECKER, J. P. Materiais Magnéticos Doces e Materiais Ferromagnéticos Amorfos. Revista Brasileira de Ensino de Física, São Paulo, v. 22, n. 3, p. 396-405, 2000. 